\title{
Optimization of sequencing batch reactor for wastewater treatment using chemically enhanced primary treatment as a pre-treatment
}

\author{
Haroon R Mian*, Sajjad Haydar Ghulam Hussain and Gul-e-Hina \\ Institute of Environmental Engineering and Research, University of Engineering and Technology Lahore
}

\begin{abstract}
The sequencing batch reactor (SBR) is a wastewater treatment option feasible for low flows. The objective of this research was to optimize SBR by varying its operational parameters, viz. (i) settling time and (ii) reaction time. The study was conducted in two phases. In Phase 1, raw wastewater was fed into the SBR after conventional settling, while in Phase 2 raw wastewater was fed into the SBR after coagulation-flocculation-sedimentation. A bench-scale model was set up and domestic wastewater was used for this study. Performance of the treatment system was evaluated through 5-day biochemical oxygen demand (BOD), chemical oxygen demand (COD) and total suspended solids (TSS). The results demonstrated that reaction time was reduced to $4 \mathrm{~h}$ in Phase 2 compared to $10 \mathrm{~h}$ in Phase 1 . The BOD, COD and TSS removal efficiencies observed in Phase 1 were $80 \%, 80 \%$ and $73 \%$, respectively, and for Phase 2 the removal efficiencies were $74 \%, 75 \%$ and $80 \%$ respectively. National Environmental Quality Standards (NEQS) were met in both cases and the treatment cost per cubic metre of wastewater for Phase 2 was 2.5 times lower compared to Phase 1 .
\end{abstract}

Keywords: CEPT, reaction time, SBR, sedimentation, settling time, wastewater

\section{INTRODUCTION}

Water pollution is one of the major environmental issues faced by the world. Increasing levels of contaminants and pollution are affecting both humans and ecological systems (Jadhav and Mahajan, 2013). Developing countries are disposing huge amounts of domestic and industrial wastewater into streams and rivers, without any proper treatment. Poor management and weak implementation of environmental legislation is making these conditions worse (Ejaz et al., 2011). Various treatment technologies are employed to treat wastewater, sequencing batch reactors (SBR) being one of these.

SBR has been in use for wastewater treatment since the 1920s. It has proven to be successful in treating wastewater from different origins, particularly for low or varying flow patterns. Municipalities, resorts, and a number of industries, including dairy, pulp and paper, tanneries, petrochemical, landfill leachate and textiles are using SBR as a wastewater treatment alternative (Al-Rekabi et al., 2007; Chakraborty et al., 2015; Mahvi, 2008; Yeruva et al., 2015). SBRs are operated in a batch mode to achieve the desired amount of treatment. Mixed liquor can settle, and clear supernatant is taken as treated wastewater. The SBR cycle consists of 5 phase that include fill, react, settle, draw and idle. One of the greatest advantage of SBR is its flexibility in operation that can be adjusted in terms of labour and energy requirements and, more particularly, in sludge production. Therefore, the treatment cycle may be adjusted to achieve the desired treatment (Al-Rekabi et al., 2007; Yoo et al., 2006).

SBR has been used in various bench-scale studies; for example, one study focused on using SBR for the treatment of greywater. The volume of the reactor was $18 \mathrm{~L}$ and the SBR unit was operated for 4 cycle times that included 5, 6, 7 and $8 \mathrm{~h}$. Maximum

To whom all correspondence should be addressed.

空 +27+1-(250)-801-9956

e-mail: hrmian@uet.edu.pk or haroon.mian@alumni.ubc.ca Received 15 August 2016; accepted in revised form June 2018
BOD removal efficiency of $95 \%$ was observed at $7 \mathrm{~h}$ cycle time (Main and Ingavale, 2012). In another study, SBR was used to treat municipal wastewater. The removal efficiency in terms of BOD, TSS and nitrogen was $98 \%, 90 \%$ and $89 \%$, respectively, considering a cycle time of $12 \mathrm{~h}$ (Umble and Ketchum, 1997). SBR was also successful in treating wood dyeing effluents, with COD and BOD removals of $85 \%$ and $95 \%$, respectively (Penha et al., 2005). In all of the above studies, raw wastewater was fed to the SBR, which is typically referred to as conventional SBR.

Some studies have been undertaken by modifying the conventional SBR; for example, a plastic media was used at the bottom of the SBR reactor for the treatment of dairy industry wastewater. The total cycle time used was $24 \mathrm{~h}(19 \mathrm{~h}$ for aeration/reaction phase, $3 \mathrm{~h}$ for settling phase and $2 \mathrm{~h}$ for fill phase). The removal efficiencies for COD and BOD increased by $5-7 \%$ with the aforementioned modification compared to conventional SBR (Sirianuntapiboon et al., 2005). In another study an improvement in treatment efficiency of SBR was observed for textile wastewater by combining biological treatment and adsorption using a low-cost absorbent, for example, a metal hydroxide sludge from the electroplating industry. This modification increased the BOD removal efficiency by $10 \%$ when compared with the removal efficiency of conventional SBR. In addition, a cycle time of $12 \mathrm{~h}$ was used in the modified SBR compared to $24 \mathrm{~h}$ in conventional SBR (Santos and Boaventura, 2015).

Apart from biological wastewater treatment, another enhanced pollutant removal process exists, particularly at the primary level of wastewater treatment, termed chemically enhanced primary treatment (CEPT). Usually, metal salts or polymers are used in CEPT(Haydar and Aziz, 2009a; Haydar and Aziz, 2009b; Haydar and Aziz, 2009c; Johnson et al., 2008; Mahmoud, 2009; Mikelonis. 2008; Sarparastzadeh et al., 2007; Song et al., 2004). Some researchers have employed CEPT prior to SBR for treating wastewater. This was a continuation of applying various modifications to conventional SBR in order to enhance the knowledge related to SBR treatment and removal efficiency. One such study includes municipal wastewater 
treatment using poly-aluminium chloride and coagulant followed by SBR. The removal efficiency achieved for BOD, COD and TSS were above $90 \%$ with a cycle time of $12 \mathrm{~h}$ (Lin and Cheng, 2001). In view of the foregoing, it may be concluded that among various modifications studied, a CEPT-SBR combination gave the most encouraging results with respect to removals. In addition, a reduced cycle time was observed in some studies using modification, which can significantly affect the cost of treatment. However, these studies focused on SBR treatment by considering either the total cycle time or using some modification, but none considered optimization by identifying the separate effects of reaction and settling time on removal efficiency. These two parameters significantly affect the treatment efficiency and concomitant cost of treatment. Therefore, the present research was undertaken to fill this gap for conventional and modified SBR, known as the CEPT-SBR system. The reaction and settling time were varied with and without CEPT to arrive at the best arrangement, which provides better removal efficiency and at the same time is cost effective.

\section{METHODS}

\section{Sampling}

Main Outfall is the largest wastewater disposal point in Lahore. It discharges about $518400 \mathrm{~m}^{3} /$ day of wastewater into Ravi River (Haider and Ali, 2016). Grab wastewater samples were collected on a bi-weekly basis from Main Outfall from July to September, 2014. Ten (10) samples were collected. The collected samples were transported in $20 \mathrm{~L}$ containers to the Institute of Environmental Engineering and Research (IEER) within $40 \mathrm{~min}$. These were preserved according to procedure 1060(C) (AWWA. 2012).

\section{Wastewater characterization}

Wastewater was characterized by conducting the tests and procedures listed in Table 1. Each parameter was tested for the raw wastewater as collected and aftera plain sedimentation (settling) of $45 \mathrm{~min}$. Thus the words 'raw' and 'settled' are prefixed with the parameter name to indicate this arrangement. Tests on raw wastewater was conducted for the purpose of characterization and to determine the removal efficiency of the SBR system. In addition, tests on settled wastewater were done merely to evaluate the effect of plain settling on various wastewater quality parameters.

\section{Suitable coagulant and optimum dose}

Two coagulants, aluminium sulfate (alum) and ferric chloride $\left(\mathrm{FeCl}_{3}\right)$ were examined. The jar test was used to find the suitable coagulant and its optimum dose. The $\mathrm{pH}$ of wastewater after applying coagulant and sludge production were the two important considerations in selecting the coagulant. Alum's working $\mathrm{pH}$ range is between 4 and 8 and that of ferric chloride is between 3.5 and 6.5 and above 8.5 (McGhee and Steel, 1991). As indicated in Table 2, the $\mathrm{pH}$ of the raw wastewater was measured to indicate the need for $\mathrm{pH}$ adjustment for the coagulants. In addition, sludge production at optimum dose was measured using Imhoff cone.

\section{Preparation of bacterial culture}

In order to seed the SBR and to introduce viable organisms, bacterial culture was used. Specific bacteria present in sampled domestic wastewater were isolated and preserved in a test

\begin{tabular}{|l|c|c|}
\hline \multicolumn{3}{|c|}{ PABLE 1 } \\
Parameters tested and testing procedures \\
\hline Parameter & Procedure number** & Reference \\
\hline $\mathrm{pH}$ & $4500-\mathrm{H}^{+}$ & \\
\hline $\mathrm{DO}$ & $4500-\mathrm{O}(\mathrm{B})$ & \multirow{2}{*}{ (AWWA, 2012) } \\
\hline $\mathrm{BOD}_{5}$ & $5210(\mathrm{~B})$ & \\
\hline $\mathrm{COD}$ & $5220(\mathrm{~B})$ & \\
\hline TSS & $2540(\mathrm{D})$ & \\
\hline
\end{tabular}

${ }^{*}$ Detailed procedure of mentioned parameters can be found using the respective procedure numbers in AWWA (2012)

tube. Test tubes were stored at $4^{\circ} \mathrm{C}$ for further use. Cultures were prepared using nutrient broth and isolated tubes. The procedure for preparing bacterial culture was as follows:

- Media preparation: Sample of nutrient broth was taken and a $100 \mathrm{~mL}$ solution was prepared as per instruction.

- Autoclave: The sample was autoclaved for $20 \mathrm{~min}$ at $121^{\circ} \mathrm{C}$ for complete sterilization.

- Inoculation: After sterilization, bacteria were introduced from a test tube to the flask having nutrient broth, using rod and burner. After inoculation, samples were taken to a shaker for $24 \mathrm{~h}$ at $37^{\circ} \mathrm{C}$. A fixed quantity of this culture $(15 \mathrm{~mL})$ was administered in the SBR, which helped in maintaining a constant $\mathrm{F} / \mathrm{M}$ ratio.

\section{Reactor setup}

The SBR reactor was setup in the IEER lab using an acrylic sheet (Fig. 1). The dimensions were $20 \mathrm{~cm} \times 19 \mathrm{~cm}$ x $16 \mathrm{~cm}$, with a total volume of $6 \mathrm{~L}$. Wastewater was fed to the reactor using an influent bottle and a peristaltic pump. The treated wastewater was collected from two outlets, one at $5.5 \mathrm{~cm}$ and the other at $10.5 \mathrm{~cm}$ from the bottom of the reactor. The reason for providing two outlets was to check the quality of water at different depths and thus make the results more reliable. The working volume in this study was in the range of 3-5 L. Air was supplied through an assembly of plastic tubes, diffuser stones and air pumps. The air supplied was sufficient to meet the oxygen requirements and to keep the solids portion suspended in the reactor.

\section{Operational plan of reactor}

Efficiency of the SBR was checked with and without CEPT. The details are given in the following sections.

\section{SBR operation without CEPT (conventional SBR)}

Raw wastewater was fed to the SBR reactor using a peristaltic pump. Once the reactor was filled up, prepared isolated bacteria cultures $(15 \mathrm{~mL})$ were added to the SBR. Four different reaction times $-2,4,6$ and $10 \mathrm{~h}$ - were used to study the effect of aeration on the SBR removal efficiency. After a specified reaction time, the air pumps were turned off and wastewater was allowed to settle. Hence settling time was also varied, for 2, 4, 6 and $12 \mathrm{~h}$, for each reaction time. A total number of 16 experiments were performed to study the performance of SBR in order to select the optimum combination. The BOD, COD and TSS were determined for the treated effluent under optimum conditions and compared with National Environmental Quality Standards (NEQS) (Government of Pakistan, 2000). Figure 2 shows the arrangement of the SBR treatment without CEPT. 


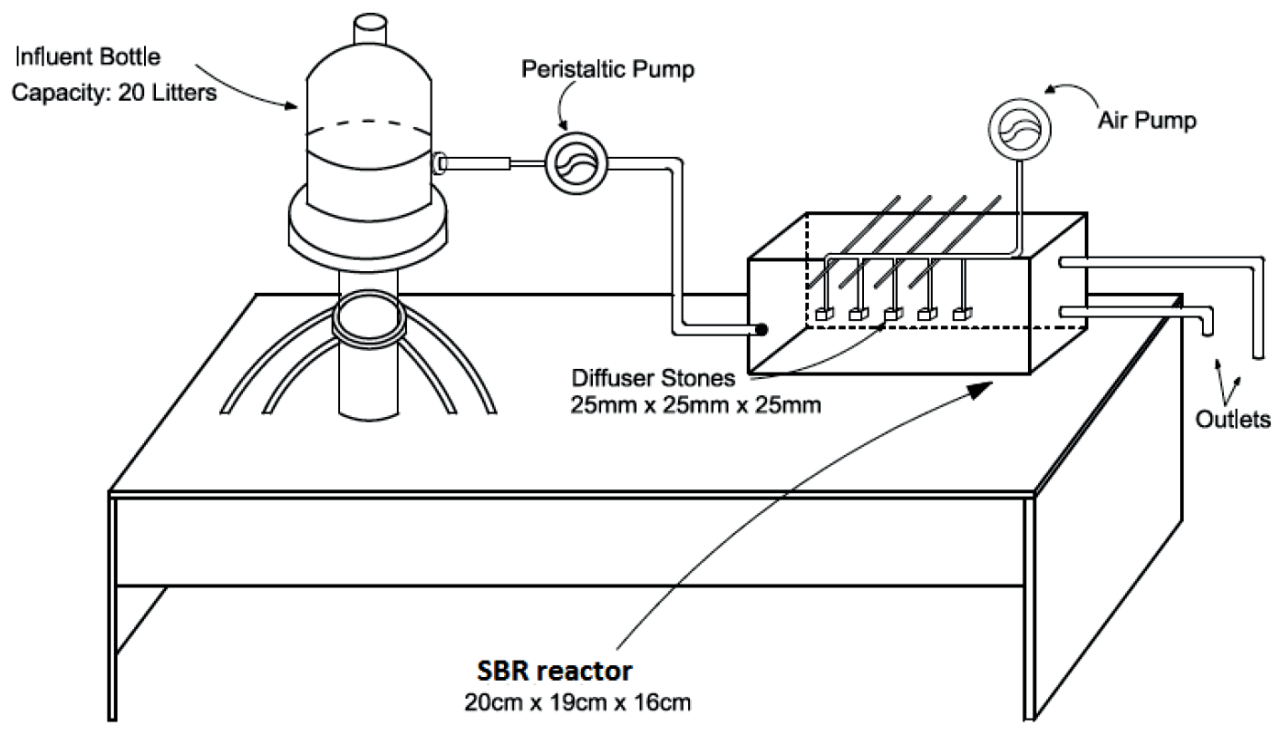

Figure 1

$S B R$ reactor setup

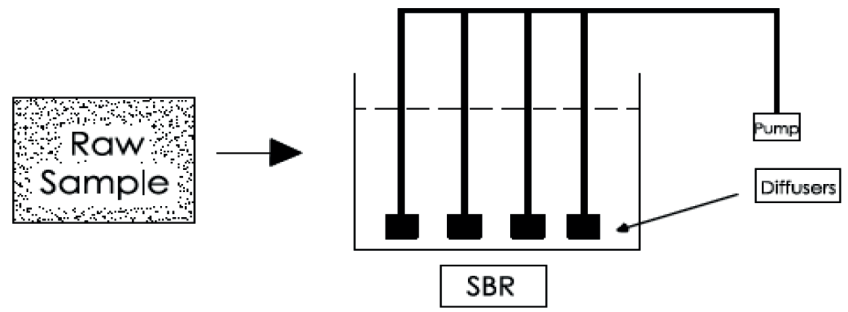

Figure 2

SBR treatment without CEPT (conventional SBR)

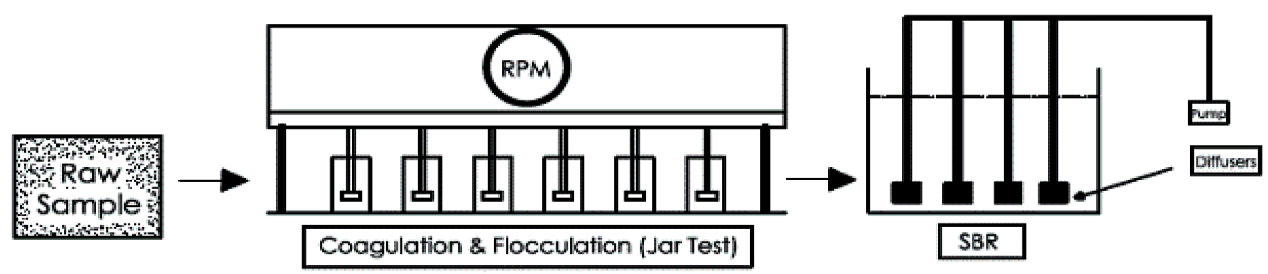

Figure 3

SBR treatment with CEPT

\section{SBR operation with CEPT (CEPT-SBR system)}

SBR operation was also studied with wastewater pre-treated with CEPT. Figure 3 shows the arrangement of CEPT-SBR system treatment. Both reaction and settling time were varied as per the procedure outliner earlier (conventional SBR). The BOD, COD and TSS were determined for the treated effluent under optimum conditions and compared with NEQS (Government of Pakistan, 2000).

\section{Calculation of removal efficiency}

Removal efficiency for both systems was calculated by comparing the raw wastewater and treated effluent concentrations.

\section{Cost analysis}

Operational cost was also evaluated for conventional SBR and CEPT-SBR system. The optimum conditions were used to calculate the costs, which included the electricity cost used to treat one cubic metre of wastewater using two air pumps (each pump had a power requirement of $63 \mathrm{~W}$ ) and the cost of coagulant. An electricity tariff of $0.15 \mathrm{USD} / \mathrm{kWh}$ was used (LESCO, 2014). The coagulant costs were 19.63 USD $/ \mathrm{kg}$ for alum and $21.65 \mathrm{USD} / \mathrm{kg}$ for ferric chloride. 


\section{RESULTS AND DISCUSSION}

\section{Characterization of wastewater}

Wastewater characterization results are shown in Table 2. Raw BOD for wastewater samples varied between 173 and $216 \mathrm{mg} / \mathrm{L}$, with a mean value of $191 \mathrm{mg} / \mathrm{L}$. The average values for raw TSS and COD were 196 and $331 \mathrm{mg} / \mathrm{L}$, respectively. There was high variation in TSS, with the coefficient of variation (CV) for TSS being the highest for all parameters. The $\mathrm{pH}$ also remained in a range that is suitable for biological treatment.

\section{Conventional SBR system}

Figures 4 to 6 show the change in effluent condition with respect to BOD, COD and TSS, respectively, by varying reaction and settling time. It can be deduced that the removal efficiency increased by increasing reaction and settling time for BOD and COD; however, in the case of TSS this trend changed slightly. Considering settling time up to $6 \mathrm{~h}$, the effluent concentrations of BOD, COD and TSS kept decreasing with an increase in settling time. Beyond $6 \mathrm{~h}$, there was no significant decrease observed. Thus, $6 \mathrm{~h}$ was adopted as the optimum settling time.

The optimum reaction times were observed under the selected optimum settling time. The highest removal efficiency range was observed with $10 \mathrm{~h}$ reaction time for BOD and COD. Hence, this was selected as the optimum reaction time. For TSS removal, both $4 \mathrm{~h}$ and $6 \mathrm{~h}$ reaction times appeared to be suitable in terms of removal efficiency. However, it is not practical to adopt a dual reaction time in one reactor, for example one for BOD and COD and one for TSS. Therefore, for practical purposes the optimum reaction time $(10 \mathrm{~h})$ initially selected for BOD and COD was taken as the design reaction time for conventional SBR. NEQS were met for BOD, COD and TSS under optimum conditions.

Table 3 shows the removal efficiencies and effluent concentrations of BOD, COD and TSS for conventional SBR under optimum conditions.

Figure 7 shows a slight variation in $\mathrm{pH}$ with increase in reaction time and settling time when compared with raw wastewater condition.

\begin{tabular}{|l|l|c|c|c|c|c|}
\hline \multicolumn{7}{|c|}{ Characterization of wastewater } \\
\hline $\begin{array}{l}\text { Sr. } \\
\text { No. }\end{array}$ & Parameter & $\begin{array}{c}\text { Min } \\
(\mathrm{mg} / \mathrm{L})\end{array}$ & $\begin{array}{c}\text { Max } \\
(\mathrm{mg} / \mathrm{L})\end{array}$ & $\begin{array}{c}\text { Mean } \\
(\mathrm{mg} / \mathrm{L})\end{array}$ & SD & CV $\%$ \\
\hline 1 & Raw BOD & 173 & 216 & 191 & 14 & 7.5 \\
\hline 2 & Settled BOD & 138 & 160 & 147 & 8 & 5.6 \\
\hline 3 & Raw COD & 300 & 360 & 331 & 22 & 6.8 \\
\hline 4 & Settled COD & 180 & 236 & 201 & 22 & 10.7 \\
\hline 5 & Raw TSS & 120 & 280 & 196 & 54 & 27.6 \\
\hline 6 & Settled TSS & 60 & 170 & 110 & 35 & 32.2 \\
\hline 7 & Raw pH & 6.98 & 7.78 & NA & NA & NA \\
\hline 8 & Settled pH & 7.04 & 7.87 & NA & NA & NA \\
\hline
\end{tabular}

\begin{tabular}{|l|l|l|l|}
\hline $\begin{array}{l}\text { TABLE } 3 \\
\text { Conventional SBR treatment results under optimum } \\
\text { condition }\end{array}$ \\
\hline & BOD & COD & TSS \\
\hline Removal efficiency & $80 \%$ & $80 \%$ & $73 \%$ \\
\hline Effluent concentration & $38 \mathrm{mg} / \mathrm{L}$ & $68 \mathrm{mg} / \mathrm{L}$ & $53 \mathrm{mg} / \mathrm{L}$ \\
\hline NEQS & $80 \mathrm{mg} / \mathrm{L}$ & $150 \mathrm{mg} / \mathrm{L}$ & $150 \mathrm{mg} / \mathrm{L}$ \\
\hline
\end{tabular}
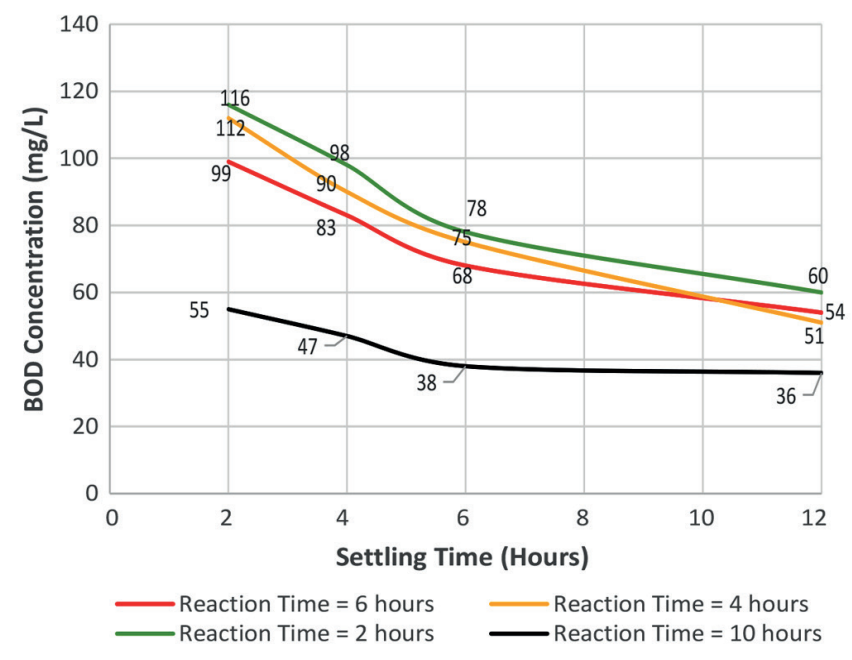

Figure 4

$B O D$ variation by changing reaction and settling time

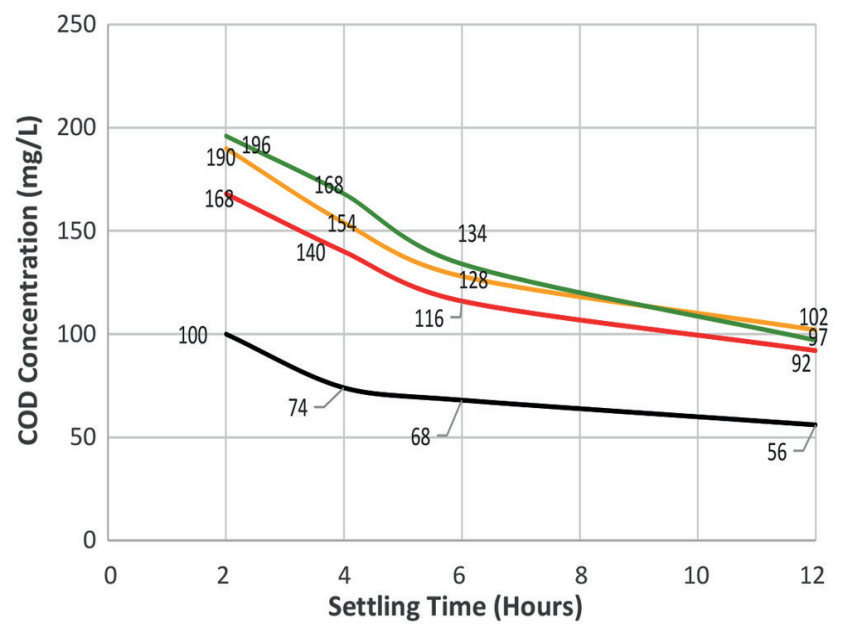

Reaction Time $=6$ hours Reaction Time $=4$ hours

Reaction Time $=2$ hours Reaction Time $=10$ hours

Figure 5

COD variation by changing reaction and settling time

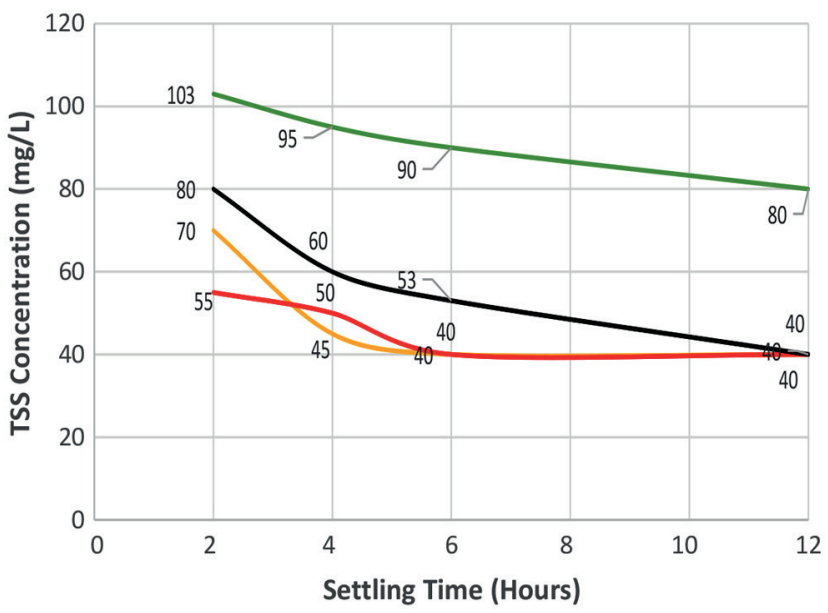

Reaction Time $=2$ hours $\quad$ Reaction Time $=4$ hours

Figure 6

TSS variation by changing reaction and settling time 


\section{Selection of suitable coagulant and optimum dose}

The jar test results are shown in Fig. 8. The optimum doses for alum and ferric chloride were $74 \mathrm{mg} / \mathrm{L}$ and $50 \mathrm{mg} / \mathrm{L}$, respectively, and sludge production was $10 \mathrm{~mL} / \mathrm{L}$ and $45 \mathrm{~mL} / \mathrm{L}$, respectively. Ferric chloride was found to have more rapid sludge settling compared with alum. In addition, ferric chloride produced several times more sludge than alum (Davis, 2010; Yonge, 2012). The working of a coagulant is also dependent on $\mathrm{pH}$, which can be a major reason for this significant difference in sludge production (Koohestanian et al., 2008). In case of alum, no pH adjustment was required as the wastewater $\mathrm{pH}$ was in the working range of the coagulant. However, for ferric chloride $\mathrm{pH}$ was adjusted to 11.2.

Based on the results, alum appears to be a suitable coagulant for the following reasons.

- Alum produces less sludge hence less sludge handling costs.

- Ferric chloride imparted colour to wastewater.

- Alum showed results within a $\mathrm{pH}$ range that is suitable for biological treatment. However, ferric chloride needs $\mathrm{pH}$ adjustment at multiple stages. For example, $\mathrm{pH}$ adjustment of wastewater is required before applying this coagulant to make it work in CEPT. Similarly, after applying CEPT pH must again be adjusted to enable biological treatment. Hence, the use of ferric chloride would be costly.

\section{SBR operation with CEPT (CEPT-SBR system)}

Figures 9 to 11 indicate the effluent condition of BOD, COD and TSS, respectively, for the CEPT-SBR system. The removal
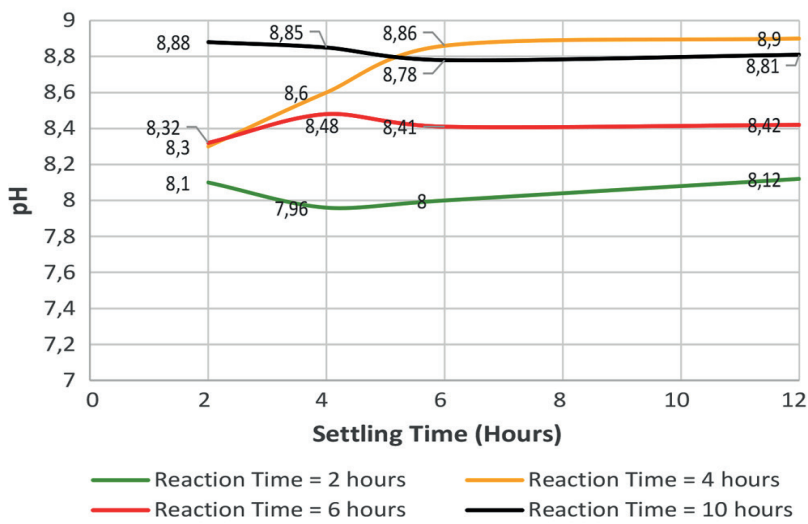

Figure 7

pH variation in conventional SBR

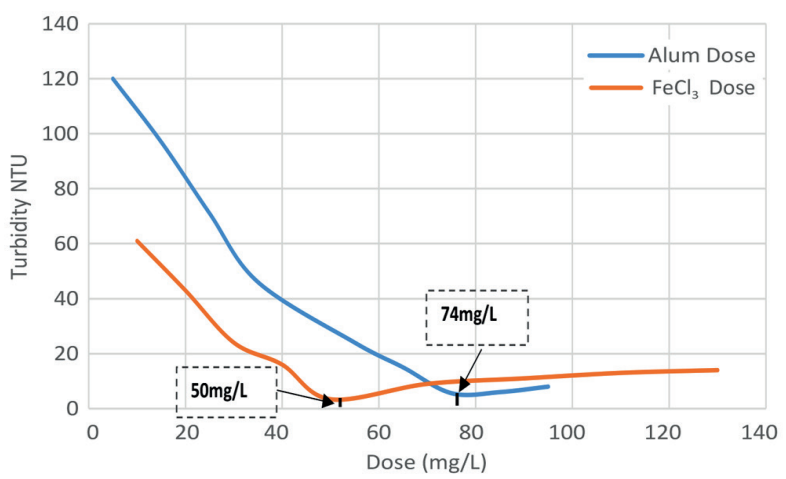

Figure 8

Jar test operation results

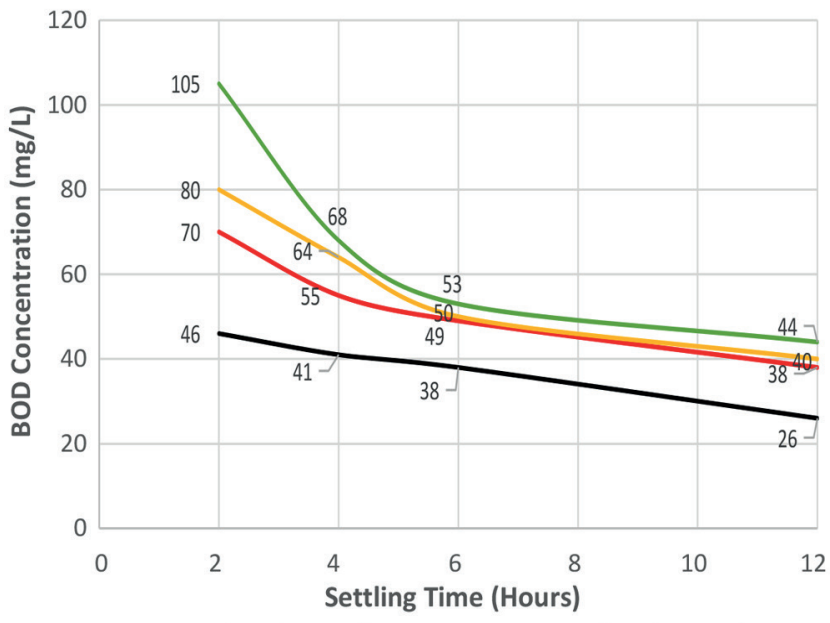

$\begin{array}{ll}\text { Reaction Time }=2 \text { hours } & \text { Reaction Time }=6 \text { hours } \\ \text { Reaction Time }=4 \text { hours } & \text { Reaction Time }=10 \text { hours }\end{array}$

Figure 9

CEPT-SBR system analysis for $B O D$

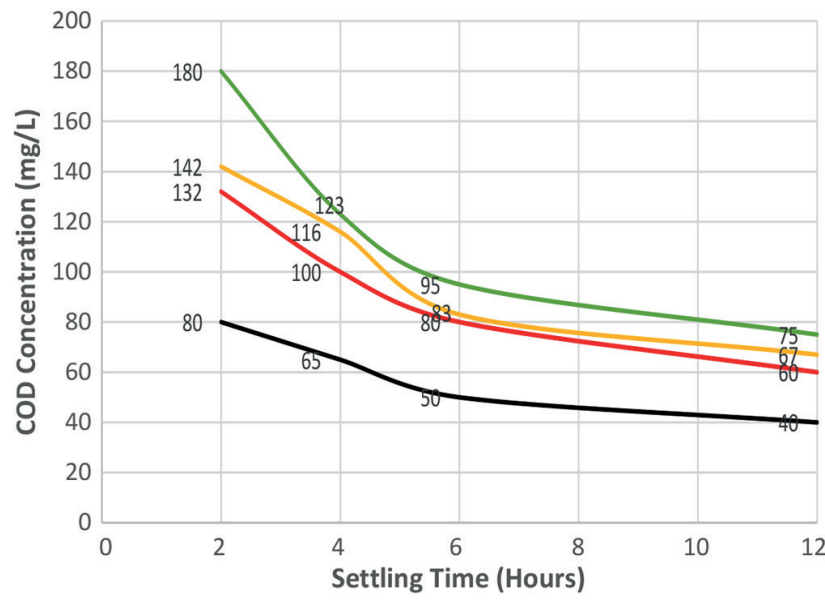

$\begin{array}{ll}\longrightarrow \text { Reaction Time }=2 \text { hours } & \text { Reaction Time }=6 \text { hours } \\ \text { Reaction Time }=4 \text { hours } & \text { Reaction Time }=10 \text { hours }\end{array}$

Figure 10

CEPT-SBR system analysis for COD

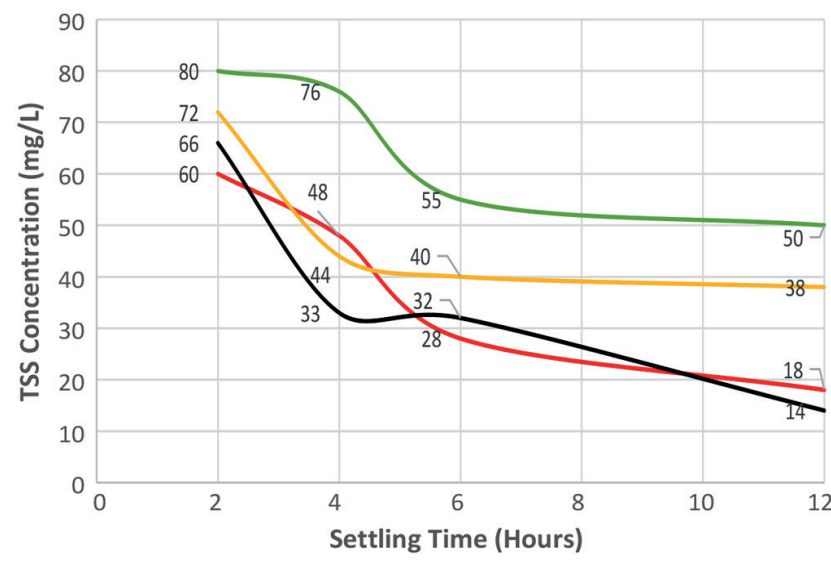
$\begin{array}{ll}\text { Reaction Time }=2 \text { hours } & \text { Reaction Time }=6 \text { hours } \\ \text { Reaction Time } & =4 \text { hours }\end{array}$

Figure 11

CEPT-SBR system analysis for TSS 
efficiency increases by increasing reaction and settling time for $\mathrm{BOD}$ and COD. The effluent concentrations of BOD, COD and TSS kept on decreasing with an increase in settling time up to $6 \mathrm{~h}$; thereafter, no significant removal occurred. Thus 6 hours was adopted as the optimum settling time.

Considering the optimum settling time, a suitable reaction time was selected. The removal efficiencies achieved at $4 \mathrm{~h}$ and $6 \mathrm{~h}$ reaction times were approximately equal for BOD and COD. In addition, these removal efficiencies were almost the same when compared to conventional SBR removal efficiencies under selected optimum conditions. For TSS, both $6 \mathrm{~h}$ and $10 \mathrm{~h}$ reaction times gave the maximum removal efficiency for the CEPT-SBR system. However, the $4 \mathrm{~h}$ reaction time still gave the higher removal efficiency compared to that achieved in conventional SBR under optimum conditions. Therefore, as it is not practical to adopt a dual reaction time, a reaction time of $4 \mathrm{~h}$ was selected among all feasible options for the CEPT-SBR system. NEQS were met for all the parameters in CEPT-SBR system under optimum conditions.

Table 4 shows the removal efficiencies and effluent concentrations of BOD, COD and TSS under the selected optimum conditions for the CEPT-SBR system.

Figure 12 shows that the $\mathrm{pH}$ dropped in the CEPT-SBR system, due to the addition of alum during jar test operation (Barkoh et al., 2013). However, the observed change was not that significant. The $\mathrm{pH}$ during the conventional SBR process remained between 8.1 and 8.9, whereas after applying CEPT the $\mathrm{pH}$ dropped to 7-7.82.

\section{Summary of comparison between conventional and CEPT-SBR system}

For conventional SBR, a reaction time of $10 \mathrm{~h}$ and settling time of $6 \mathrm{~h}$ were selected as optimal. However, in the CEPT-SBR

\begin{tabular}{|l|c|c|c|}
\hline \multicolumn{4}{|c|}{ TABLE 4 } \\
CEPT-SBR system treatment results under optimum \\
conditions
\end{tabular}
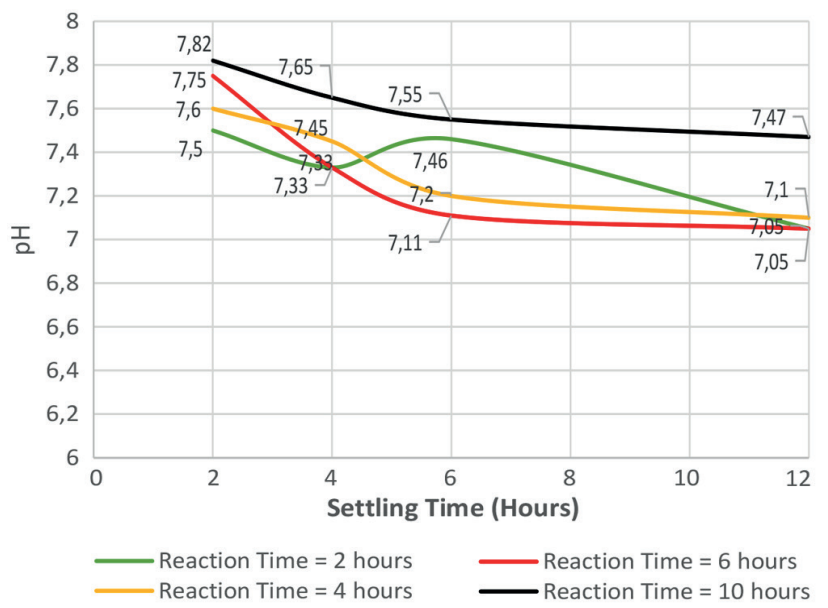

Figure 12

pH variation in CEPT-SBR system system a reaction time of $4 \mathrm{~h}$ and settling time of $6 \mathrm{~h}$ gave the best results. A comparison of removal efficiencies under optimum conditions for both systems is shown in Fig. 13.

Figure 13 shows that removal efficiencies of both systems were comparable, considering the $10 \mathrm{~h}$ reaction time of conventional SBR and $4 \mathrm{~h}$ reaction time of the CEPT-SBR system. The BOD and COD removal efficiencies were 5-6\% higher in conventional SBR compared to the CEPT-SBR system. However, the CEPT-SBR system gave 7\% better removal efficiency for TSS.

The comparison of effluent condition, under optimum conditions, for conventional SBR and CEPT-SBR system is shown in Fig. 14.

Figure 14 shows that effluent concentration from conventional SBR was slightly lower when compared with CEPT-SBR system for BOD and COD. However, lower TSS concentrations were achieved in CEPT-SBR system.

\section{Cost analysis}

The cost comparison for treating 1 cubic metre of wastewater using conventional SBR and CEPT-SBR system under optimum conditions is shown in Fig. 15.

Figure 15 shows that cost per cubic metre of wastewater for conventional SBR was approximately 2.5 times greater in comparison to CEPT-SBR system under optimum conditions. Only energy costs are entailed in conventional SBR, whereas in CEPT-SBR system there is an additional cost of coagulant along with the energy cost. However, the total cost of the CEPT-SBR system was lower, due to the reduction in reaction time, which made the CEPT-SBR system a better option.

$$
\text { e Conventional SBR =CEPT-SBR System }
$$

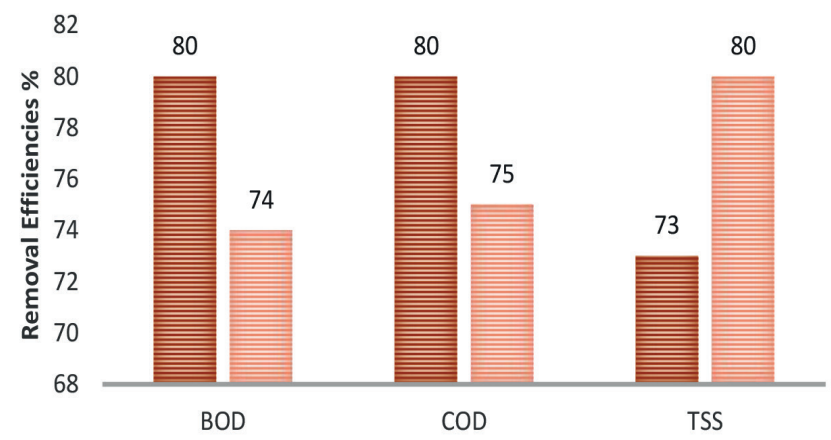

Figure 13

Removal efficiencies comparison of both systems

E Conventional SBR 를 CEPT-SBR System

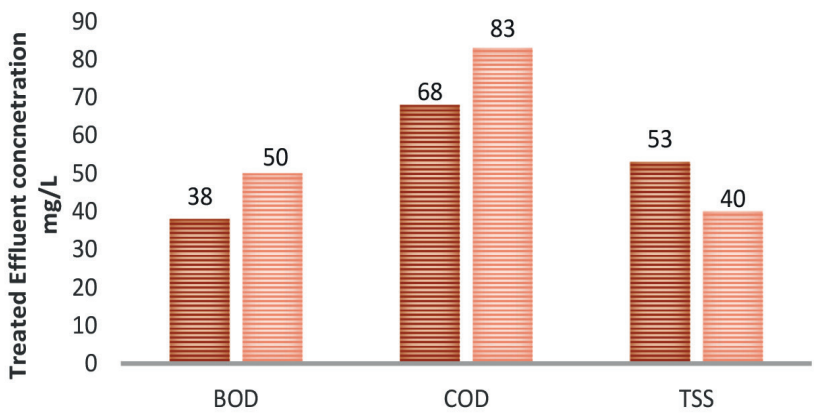

Figure 14

Treated effluent condition comparison of both systems 


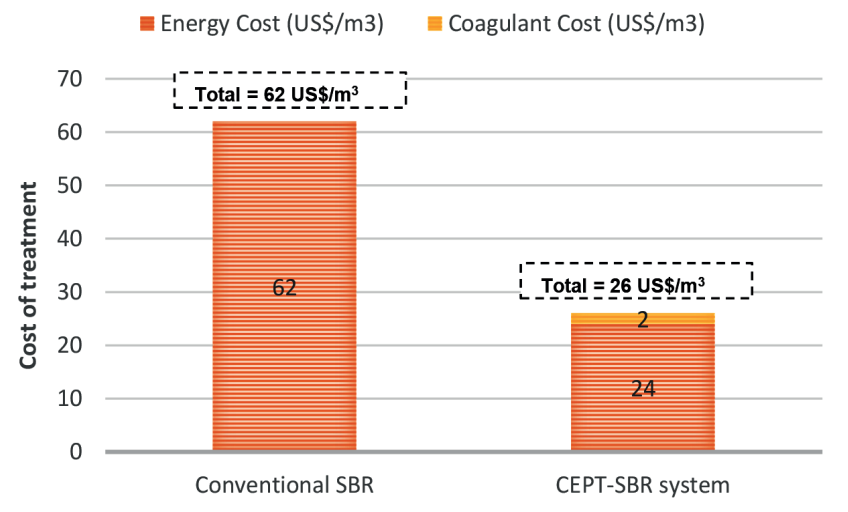

Figure 15

Cost comparison of both systems

\section{CONCLUSIONS}

The following conclusions may be drawn from this study:

- In conventional SBR, the optimum reaction and settling time were $10 \mathrm{~h}$ and $6 \mathrm{~h}$, respectively. The BOD, COD and TSS removal under optimum conditions ranged between 73 and $80 \%$. The effluent concentration for BOD, COD and TSS were $38 \mathrm{mg} / \mathrm{L}, 68 \mathrm{mg} / \mathrm{L}$ and $53 \mathrm{mg} / \mathrm{L}$, respectively.

- Alum was a better choice for CEPT-SBR system treatment with an optimum dose of $74 \mathrm{mg} / \mathrm{L}$. It also produced less sludge (10 mL/L against $45 \mathrm{~mL} / \mathrm{L}$ for ferric chloride).

- In the CEPT-SBR system, the optimum reaction and settling times determined were $4 \mathrm{~h}$ and $6 \mathrm{~h}$, respectively. BOD, COD and TSS removal under optimum conditions ranged between 74 and $80 \%$. The effluent concentrations for BOD, COD and TSS were $50 \mathrm{mg} / \mathrm{L}, 83 \mathrm{mg} / \mathrm{L}$ and $40 \mathrm{mg} / \mathrm{L}$, respectively.

- Comparing both systems, the optimum reaction time in CEPT-SBR system has been reduced to $4 \mathrm{~h}$, compared to the $10 \mathrm{~h}$ reaction time of conventional SBR for all parameters.

- Cost comparison showed CEPT-SBR system to be a better choice.

\section{REFERENCES}

AL-REKABI WS, QIANG H and QIANG WW (2007) Review on sequencing batch reactors. Pakistan Journal of Nutrition 6 (1) 11-19. https://doi.org/10.3923/pjn.2007.11.19

AWWA (2012) Standard Methods for the Examination of Water and Wastewater (22 ${ }^{\text {nd }}$ edn). American Public Health Association, American Water Works Association, Water Environment Federation, Washington, DC. 1496 pp.

BARKOH A, KURTEN GL, BEGLEY DC and FRIES LT (2013) Use of aluminum sulfate to reduce ph and increase survival in fingerling striped bass production ponds fertilized with nitrogen and phosphorus. N. Am. J. Aquacult. 75 (3) 377-384. https://doi.org/10.1 080/15222055.2013.786004

CHAKRABORTY S, RANJAN K, VERMA M, IQBAL J and NARESH $R$ (2015) Assessing the feasibility of co-treatment of landfill leachate and municipal wastewater in sequencing batch reactor (SBR). In: Proceedings of International Conference on Sustainable Energy and Built Environment. 574-578.

DAVIS ML (2010) Water and Wastewater Engineering. McGraw-Hill, New York.

EJAZ N, HASHMI HN and GHUMMAN AR (2011) Water quality assessment of effluent receiving streams in Pakistan: A case study of Ravi River. Mehran Univ. Res. J. Eng. Technol. 30 (3) 383-396.

GOVERNMENT OF PAKISTAN (2000) National Environmental Quality Standards for municipal and liquid industrial effluents. Annex I. Government of Pakistan, Islamabad.

HAIDER H and ALI W (2016) Diurnal variations in wastewater characteristics at Main Outfall in Lahore. Pakistan J. Eng. Appl. Sci. $106-20$

HAYDAR S and AZIZ JA (2009a) Characterization and treatability studies of tannery wastewater using chemically enhanced primary treatment (CEPT) - a case study of Saddiq Leather Works. J. Hazardous Mater. 163 (2) 1076-1083. https://doi.org/10.1016/j. jhazmat.2008.07.074

HAYDAR S and AZIZ JA (2009b) Coagulation-flocculation studies of tannery wastewater using cationic polymers as a replacement of metal salts. Water Sci. Technol. 59 (2) 381-390. https://doi. org/10.2166/wst.2009.864

HAYDAR S and AZIZ JA (2009c) Coagulation-flocculation studies of tannery wastewater using combination of alum with cationic and anionic polymers. J. Hazardous Mater. 168 (2) 1035-1040. https:// doi.org/10.1016/j.jhazmat.2009.02.140

JADHAV MV and MAHAJAN YS (2013) Investigation of the performance of chitosan as a coagulant for flocculation of local clay suspensions of different turbidities. KSCE J. Civ. Eng. 17 (2) 328-334. https://doi.org/10.1007/s12205-013-2021-2

JOHNSON PD, GIRINATHANNAIR P, OHLINGER KN, RITCHIE S, TEUBER L and KIRBY J (2008) Enhanced removal of heavy metals in primary treatment using coagulation and flocculation. Water Environ. Res. 80 (5) 472-479. https://doi. org/10.2175/106143007X221490

KOOHESTANIAN A, HOSSEINI M and ABBASIAN Z (2008) The separation method for removing of colloidal particles from raw water. Am.-Eurasian J. Agric. Environ. Sci. 4 (2) 266-273.

LESCO (2014) Electricity Tariff. 2015 (April 2). LESCO, Lahore.

LIN SH and CHENG KW (2001) A new sequencing batch reactor for treatment of municipal sewage wastewater for agricultural reuse. Desalination 133 (1) 41-51. https://doi.org/10.1016/S0011-9164(01)00081-9

MAHMOUD EK (2009) Chemically enhanced primary treatment of textile industrial effluents. Pol. J. Environ. Stud. 18 (4) 651-655.

MAHVI AH (2008) Sequencing batch reactor: a promising technology in wastewater treatment. J. Environ. Health Sci. Eng. 5 (2) 79-90.

MAIN JS and INGAVALE BC (2012) Sequencing batch reactor for greywater treatment. EXCEL Int. J. Multidiscipl. Manage. Stud. 2 88-107.

MCGHEE TJ and STEEL EW (1991) Water Supply and Sewerage. McGraw-Hill, New York.

MIKELONIS AM (2008) Chemically enhanced primary treatment of wastewater in Honduran Imhoff tanks. Doctoral dissertation, Massachusetts Institute of Technology.

SANTOS SC and BOAVENTURA RA (2015) Treatment of a simulated textile wastewater in a sequencing batch reactor (SBR) with addition of a low-cost adsorbent. J. Hazardous Mater. 291 74-82. https://doi.org/10.1016/j.jhazmat.2015.02.074

SARPARASTZADEH H, SAEEDI M, NAEIMPOOR F and AMINZADEH B (2007) Pretreatment of municipal wastewater by enhanced chemical coagulation. Int. J. Environ. Res. 1 (2) 104-113.

SIRIANUNTAPIBOON S, JEEYACHOK N and LARPLAI R (2005) Sequencing batch reactor biofilm system for treatment of milk industry wastewater. J. Environ. Manage. 76 (2) 177-183. https:// doi.org/10.1016/j.jenvman.2005.01.018

SONG Z, WILLIAMS CJ and EDYVEAN R (2004) Treatment of tannery wastewater by chemical coagulation. Desalination 164 (3) 249-259. https://doi.org/10.1016/S0011-9164(04)00193-6

UMBLE AK and KETCHUM LH (1997) A strategy for coupling municipal wastewater treatment using the sequencing batch reactor with effluent nutrient recovery through aquaculture. Water Sci. Technol. 35 (1) 177-184. https://doi.org/10.2166/wst.1997.0041

YERUVA DK, JUKURI S, VELVIZHI G, KUMAR AN, SWAMY YV and MOHAN SV (2015) Integrating sequencing batch reactor with bio-electrochemical treatment for augmenting remediation efficiency of complex petrochemical wastewater. Bioresour. Technol. 188 33-42. https://doi.org/10.1016/j.biortech.2015.02.014

YONGE D (2012) A comparison of aluminum and iron-based coagulants for treatment of surface water in Sarasota County, Florida. Masters dissertation, University of Central Florida.

YOO CK, LEE I and VANROLLEGHEM PA (2006) On-line adaptive and nonlinear process monitoring of a pilot-scale sequencing batch reactor. Environ. Monit. Assess. 119 (1) 349-366. https://doi. org/10.1007/s10661-005-9030-7 